\title{
Expression of an Engineered Cecropin Gene Cassette in Transgenic Tobacco Plants Confers Disease Resistance to Pseudomonas syringae pv. tabaci
}

\author{
Y. Huang, R. O. Nordeen, M. Di, L. D. Owens, and J. H. McBeath
}

First, third, and fifth authors: Department of Plant and Animal Science, University of Alaska, Fairbanks 99775; second and fourth authors: United States Department of Agriculture, Plant Molecular Biology Laboratory, Beltsville, MD 20705.

Accepted for publication 7 February 1997.

\begin{abstract}
Huang, Y., Nordeen, R. O., Di, M., Owens, L. D., and McBeath, J. H. 1997. Expression of an engineered cecropin gene cassette in transgenic tobacco plants confers disease resistance to Pseudomonas syringae pv. tabaci. Phytopathology 87:494-499.

A chimeric gene fusion cassette, consisting of a secretory sequence from barley $\alpha$-amylase joined to a modified cecropin (MB39) coding sequence and placed under control of the promoter and terminator from the potato proteinase inhibitor II (PiII) gene, was introduced into tobacco by Agrobacterium-mediated transformation. Transgenic and control plants reacted differently when inoculated with tobacco wildfire pathogen Pseudomonas syringae pv. tabaci at various cell concentrations. With control plants (transformed with a PiII-GUS [ $\beta$-D-glucuronidase] gene fusion), necrosis was clearly visible in leaf tissue infiltrated with bacterial inocu-
\end{abstract}

ABSTRACT lum levels of $10^{2}, 10^{3}, 10^{4}, 10^{5}$, and $10^{6} \mathrm{CFU} / \mathrm{ml}$. With MB39-transgenic plants, however, necrosis was observed only in the areas infiltrated with the two highest levels $\left(10^{5}\right.$ and $\left.10^{6} \mathrm{CFU} / \mathrm{ml}\right)$. No necrosis was evident in areas infiltrated with bacterial concentrations of $10^{4} \mathrm{CFU} / \mathrm{ml}$ or less. Bacterial multiplication in leaves of MB39-transgenic plants was suppressed more than 10-fold compared to control plants, and absence of disease symptom development was associated with this growth suppression. We conclude that the pathogen-induced promoter and the secretory sequence were competent elements for transforming a cecropin gene into an effective disease-control gene for plants.

Additional keywords: antibacterial protein, bacterial disease resistance, plant genetic engineering.
Rapid development in recombinant DNA technologies and plant genetic transformation have made it possible to introduce selected genes into plants to confer novel phenotypes. Although some genes are introduced primarily for basic studies, other genes have shown great potential for improvement of disease resistance in agricultural crops (28). This technology has revolutionized disease control strategies in applied agriculture. Experimental successes have been reported with genes encoding antifungal proteins, such as glucanases and chitinases (3), Bacillus thuringiensis (BT) toxin directed against certain insects (24), viral coat protein, replicase genes directed against certain viruses (2), and lysozyme directed against bacterial pathogens (8).

Cecropins comprise a small family of naturally occurring lytic peptides found in Hyalophora cecropia, the giant silk moth. These peptides are small, 35 to 37 amino acid residues, strongly basic, and comprise three major forms: A, B, and D (14). Cecropins exhibit a broad spectrum of antibacterial activity against both gramnegative and -positive bacteria. This observation prompted scientists to propose the idea of using the genes cloned from insects to enhance bacterial disease resistance in plants $(4,17)$. Several cecropin-like peptides have been synthesized and shown to possess comparable or increased antibacterial activity relative to natural cecropins (16). The synthetic peptide SB-37, for example, displayed cytotoxic activity against a wide range of phytopathogenic bacteria (27). Additionally, concentrations of the SB-37 peptide lethal to protoplasts from certain plants were much higher than those required to kill their respective pathogens, suggesting that it

Corresponding author: Y. Huang; E-mail address: fnyh@ aurora.alaska.edu

Publication no. P-1997-0304-03R

(C) 1997 The American Phytopathological Society may be feasible to protect against these pathogens by introducing a modified cecropin gene into plants. Subsequently, transgenic plants containing a cecropin analogue gene were shown to have enhanced disease resistance to Burkholderia solanacearum $(13,16)$.

In this work, we report that transgenic tobacco carrying a modified cecropin gene fused to a secretory sequence and regulated by a PiII promoter and terminator exhibited enhanced disease resistance to the tobacco wildfire pathogen, Pseudomonas syringae pv. tabaci.

\section{MATERIALS AND METHODS}

Plant materials. Tobacco (Nicotiana tabacum L.) cv. Bottom Special seeds were sterilized by immersion in $95 \%$ ethanol for 45 s, followed by $5 \mathrm{~min}$ in $30 \%$ sodium hypochlorite and three rinses in sterile deionized water. Sterilized seeds were germinated and grown on Murashige and Skoog (MS) medium (26). Kanamycinresistant $(50 \mu \mathrm{g} / \mathrm{ml})$ transgenic tobacco plants were selected, rooted, and transplanted into pots containing Pro-Mix, BX (Premier Brands, Ribiere-Du-Loup, QB, Canada). Transgenic plants were maintained in a growth chamber, with $16 \mathrm{~h}$ of light $(3,000$ lux $)$ per $8 \mathrm{~h}$ of dark cycles at $25^{\circ} \mathrm{C}$. Selected transgenic lines were selfed and grown to maturity in the greenhouse.

Bacterial strains, plasmids, and growth conditions. Bacterial strains and plasmids used in this work are described in Table 1. $P$. syringae pv. tabaci strain ATCC $11528 \mathrm{R}$ (provided by D. K. Willis, University of Wisconsin, Madison) was cultured and maintained on King's medium B (20 g of peptone, $15 \mathrm{~g}$ of $\mathrm{K}_{2} \mathrm{HPO}_{4}, 15$ $\mathrm{ml}$ of glycerol, and $5 \mathrm{ml}$ of $1 \mathrm{M} \mathrm{MgSO}_{4}$ stock solution per liter) at $28^{\circ} \mathrm{C}$. Agrobacterium tumefaciens strain LBA4404 was grown and maintained on 523 medium (10 g of sucrose, $8 \mathrm{~g}$ of casein hydrolysate, $4 \mathrm{~g}$ of yeast extract, $2 \mathrm{~g}$ of $\mathrm{K}_{2} \mathrm{HPO}_{4}, 150 \mathrm{mg}$ of $\mathrm{MgSO}_{4}$, and $15 \mathrm{~g}$ of agar, $\mathrm{pH} 7.5$, per liter). Escherichia coli strain DH5 $\alpha$ was grown on Luria broth medium at $37^{\circ} \mathrm{C}$. Antibiotics were used, 
when appropriate, at the following concentrations: kanamycin at $25 \mu \mathrm{g} / \mathrm{ml}$, ampicillin at $50 \mu \mathrm{g} / \mathrm{ml}$, rifampicin at $100 \mu \mathrm{g} / \mathrm{ml}$, and streptomycin at $20 \mu \mathrm{g} / \mathrm{ml}$.

Vector construction and tobacco transformation. Binary vector pYH145 was constructed as outlined in Figure 1. The MB39 portion of pMBP39 (R. O. Nordeen, unpublished data) consists of the secretory sequence from the barley $\alpha$-amylase gene ([21]; provided by S. Muthukrishnan, Kansas State University, Manhattan) joined to the coding region of a modified synthetic cecropin gene, SB-37 ([7]; provided by J. Jaynes, Louisiana State University, Baton Rouge) by recombinant-polymerase chain reaction (PCR) amplifi- cation. The amino acid sequence specified by the MB39 coding region is shown in Figure 2. The MB39 coding sequence was placed under the control of the promoter and terminator of a potato PiII gene (19) that had been cloned into T-DNA binary vector BIN 19 to produce plasmid pS9 (provided by L. Willmitzer, Institut für Genbiologische Fouschung, Berlin). The resulting promoter fragment consisted of 1,296 bp upstream of the transcription start site and $32 \mathrm{bp}$ downstream of the start site. The PiII promoter previously had been constitutively expressed at low levels and induced by various wounding treatments in transgenic tobacco containing the PiII-GUS ( $\beta$-D-glucuronidase) gene fusion $(19,29)$. It

TABLE 1. Bacterial strains and plasmids

\begin{tabular}{lll}
\hline Strain or plasmid & \multicolumn{1}{c}{ Relevant characteristics } & Source \\
\hline $\begin{array}{l}\text { Pseudomonas syringae pv. tabaci } \\
\text { ATCC 11528R }\end{array}$ & Rif $^{\mathrm{r}}$ derivative of tobacco strain 11528 & D. K. Willis, Madison, WI \\
$\begin{array}{l}\text { Agrobacterium tumefaciens } \\
\text { LBA4404 }\end{array}$ & Carrying pAL4404 of octopine-type Ti plasmid pTiAch5 & C. I. Kado, Davis, CA \\
$\begin{array}{l}\text { Escherichia coli } \\
\text { DH5 }\end{array}$ & $\mathrm{F}^{-}$, endA1, hrdR17 $\left(\mathrm{r}_{\mathrm{k}}{ }^{-} \mathrm{m}_{\mathrm{k}}{ }^{+}\right)$recA1 & BRL, Gaithersburg, MD \\
$\begin{array}{l}\text { Plasmids } \\
\text { pUC18/19 }\end{array}$ & Cloning vector, Amp ${ }^{\mathrm{r}}$ & \\
pBLSK (pBluescript II SK[-]) & Cloning vector, Amp ${ }^{\mathrm{r}}$ & BRL, Gaithersburg, MD \\
pS9 & Ti plasmid carrying PiII-GUS ( $\beta$-D-glucuronidase) fusion & Stratagene, La Jolla, CA \\
pMBP39 & Ti plasmid carrying 35S-MB39 gene fusion & L. Willmitzer, Berlin \\
pYH145 & Ti plasmid carrying PilI-MB39 gene fusion & This study \\
\hline
\end{tabular}

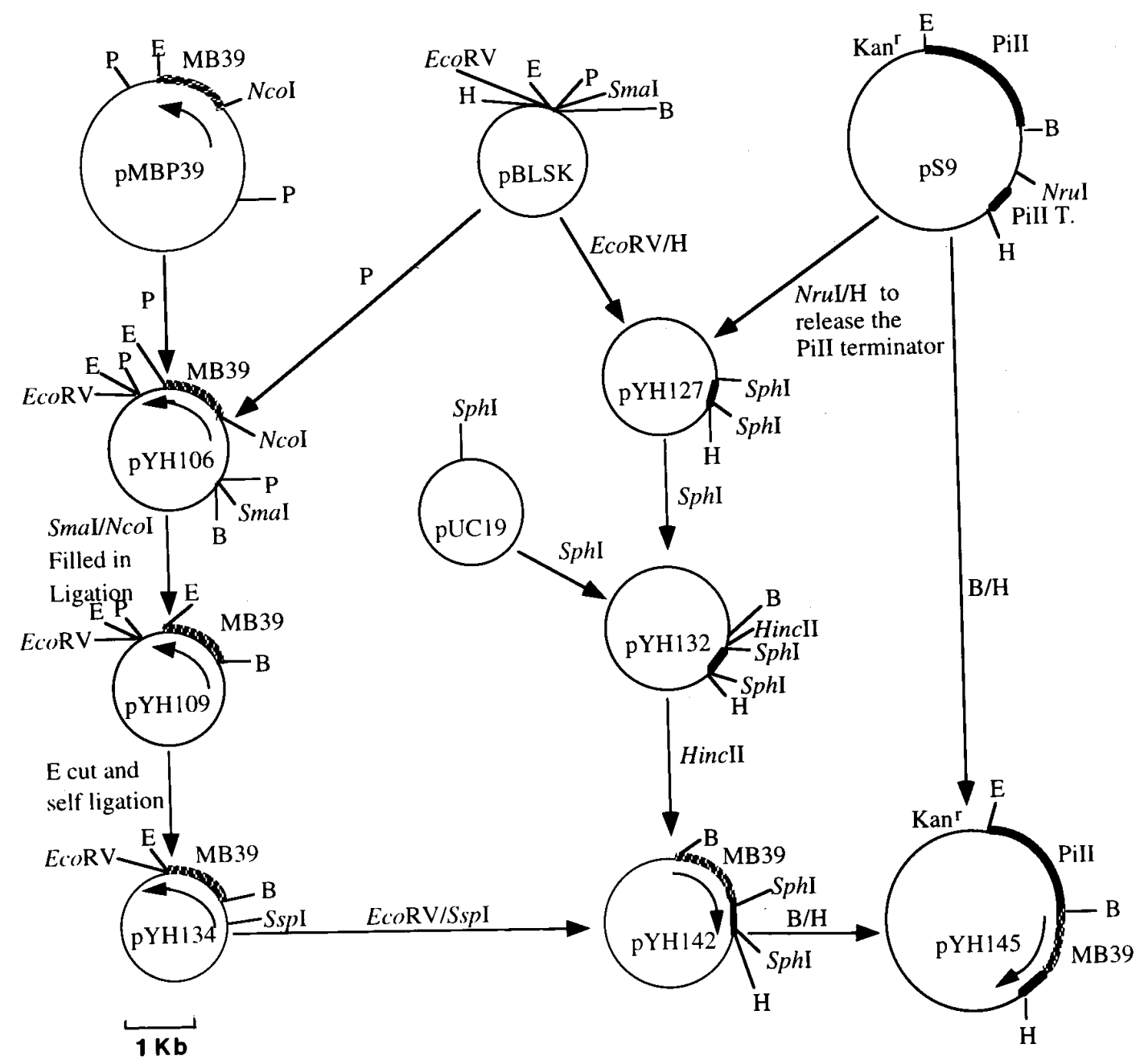

Fig. 1. Summary of cloning steps for construction of plasmid pYH145. The $\alpha$-amylase secretory sequence-MB39-PiII terminator fusion was cloned into T-DNA binary vector pS9 (a BIN 19 derivative) to yield plasmid pYH145. E = EcoRI; $\mathrm{B}=$ BamHI; $\mathrm{H}=$ HindIII; $\mathrm{P}=$ PstI; PiII T. $=$ PiII terminator; pBLSK $=$ pBluescript II SK[-]. 
also had been rapidly and systemically induced by two bacterial pathogens, $P$. syringae pv. tabaci and $B$. solanacearum, in transgenic tobacco (13).

Plasmid pYH145 was transformed into Agrobacterium helper strain LBA4404 by electroporation with a gene pulser (Bio-Rad Laboratories, Hercules, CA) following the procedure described by Cooley et al. (5). Following the method of Horsch et al. (10), this strain was used to transform tobacco. Transgenic shoots were selected on medium containing kanamycin $(100 \mu \mathrm{g} / \mathrm{ml})$. Plants carrying the intact MB39 gene, determined by PCR analysis, were transplanted into soil and grown in a growth chamber for pathogenicity testing. Transgenic tobacco plants containing the PiII-GUS (uidA coding region specifying $\beta$-glucuronidase) gene fusion were used as controls.

PCR amplification. Integration of MB39 into the plant genome was confirmed by amplification in PCR with two 21-nt oligo primers, C1 (5'-TCCGGCCATATGCCGAAATGG-3') and C2 (5'AGGATATCCTAGTTTGCGCGC-3'), that are specific to the internal region of the MB39 gene sequence. Genomic DNA from transgenic tobacco lines was extracted as previously described (18). PCR with primers $\mathrm{C} 1$ and $\mathrm{C} 2$ was performed in DNA thermal cycler 480 (Perkin-Elmer Cetus, Norwalk, CT). The following program was run: initial denaturation for $4 \mathrm{~min}$ at $94^{\circ} \mathrm{C}$, followed by 30 cycles of $45 \mathrm{~s}$ at $94^{\circ} \mathrm{C}, 1 \mathrm{~min}$ at $50^{\circ} \mathrm{C}$, and $2 \mathrm{~min}$ at $73^{\circ} \mathrm{C}$. The final extension step was for $10 \mathrm{~min}$ at $72^{\circ} \mathrm{C}$. All reactions had a final volume of $20 \mu \mathrm{l}$ and contained Tris buffer $\left(1.5 \mathrm{mM} \mathrm{MgCl}_{2}\right.$, $50 \mathrm{mM} \mathrm{KCl}$, and $10 \mathrm{mM}$ Tris, $\mathrm{pH} 8.3$ ), $0.2 \mathrm{mM}$ each of dNTP, $100 \mathrm{ng}$ of each primer, 1 unit of Taq polymerase (Perkin-Elmer Cetus), and $3 \mu \mathrm{l}$ of sample (5 to $10 \mathrm{ng}$ ). The PCR products were analyzed by running $5 \mu \mathrm{l}$ of the reaction in Tris-acetate agarose gel $(1.5 \%)$ electrophoresis, staining with ethidium bromide, and visualizing with UV light.

Pathogenicity testing. Bacterial suspensions of $P$. syringae pv. tabaci strain ATCC 11528R were prepared in sterile distilled water. Dilutions of $10^{2}, 10^{3}, 10^{4}, 10^{5}$, and $10^{6} \mathrm{CFU} / \mathrm{ml}$ were determined by the standard plate-dilution method. About $20 \mu \mathrm{l}$ of each of the five bacterial inoculum levels was individually infiltrated into the intercellular space of fully developed leaves of R0 transgenic tobacco plants (40 to 50 days old) with a hypodermic syringe fitted with a fine needle (no. 27), following the method of Klement (20). Inoculated plants were incubated in the growth chamber under conditions similar to preinoculation. Disease development was scored 7 days after inoculation.

To investigate bacterial growth rate in transgenic tobacco plants, P. syringae $\mathrm{pv}$. tabaci $\left(10^{4} \mathrm{CFU} / \mathrm{ml}\right)$ was infiltrated into leaves of control and MB39-transgenic tobacco lines. Leaf disks $(0.8 \mathrm{~cm}$ diameter) were punched from the infiltrated area with a cork borer at $0,12,24,36,48,60,72$, and $84 \mathrm{~h}$ after inoculation and macerated in sterile water with a pestle in a $50-\mathrm{ml}$ porcelain mortar. Bacterial populations at each time point were measured by the standard plate-dilution method, using King's medium B amended with rifampicin $(100 \mu \mathrm{g} / \mathrm{ml})$.

Western blot assay. To boost PiII promoter activity, $P$. syringae pv. tabaci strain ATCC $11528 \mathrm{R}\left(10^{4} \mathrm{CFU} / \mathrm{ml}\right)$ was infiltrated into leaves of MB39-transgenic tobacco lines 145 \#30, 145 \#74 and the control tobacco line. At $8 \mathrm{~h}$ after inoculation, samples of leaf tissue $(0.25 \mathrm{~g})$ were collected from the bacteria-infiltrated area and homogenized in liquid nitrogen. Total proteins were extracted ac-

\section{MGKKSHICCFSLLLLLFAGLASG}

HQPKWKVFKKIEKVGGNIRNGIVKAGPAIAVLGEAKAL

MB39

\section{KWKVFKKIEKMGRNIRNGIVKAGPAIAVLGEAKAL * Cecropin B}

Fig. 2. Sequence comparison of MB39 with the original cecropin B. The leader secretory sequence from barley $\alpha$-amylase is in bold, and differences in amino acid sequence from authentic cecropin B are underlined. The asterisk indicates an amide group that is not present in MB39. cording to the procedure of Wolpert and Dunkle (35). The protein sample $(50 \mu \mathrm{g})$ was subjected to electrophoresis in a $15 \%$ sodium dodecyl sulfate-polyacrylamide gel, using the buffer system of Laemmli (22). Separated proteins were blotted onto nitrocellulose and exposed to polyclonal rabbit antiserum raised against synthetic mature MB39 peptide. Immunoreactive bands were detected with an alkaline phosphatase immunoblot assay kit (Bio-Rad).

\section{RESULTS}

Selection of transgenic plants. In this system, a wound-inducible potato PiII promoter was fused to the upstream sequence of MB39 to provide inducible transcription control of MB39 gene expression in transgenic tobacco. Transgenic tobacco plants carrying the PilI-MB39 construct were regenerated and grown on medium containing kanamycin. Integration of the MB39 gene into the tobacco genome was confirmed by PCR analysis of total genomic DNA extracted from each transgenic line (Fig. 3). As shown in Figure 3, the transgenic line in lane 4, which failed to produce a positive MB39 gene band, also showed no disease resistance to infection by $P$. syringae pv. tabaci strain ATCC 11528R, although this transgenic line displayed a kanamycin-resistant phenotype. Fifty individual R0 transgenic lines that showed a positive MB39 gene band in the PCR assay were selected for pathogenicity testing.

MB39-transgenic plants display resistance. Three young but fully developed leaves from each of the 50 independently transformed tobacco lines were infiltrated with five different inoculum levels of $P$. syringae pv. tabaci. The infiltration pattern and disease response on leaves from two R0 transgenic lines and a control plant are shown in Figure 4. Infiltration of control tobacco leaves with all five levels of bacterial inoculum of $P$. syringae pv. tabaci resulted in visible necrosis within the infiltrated areas at 7 days after infiltration. With the two MB39-transgenic lines, however, necrosis was observed only in areas infiltrated with the two

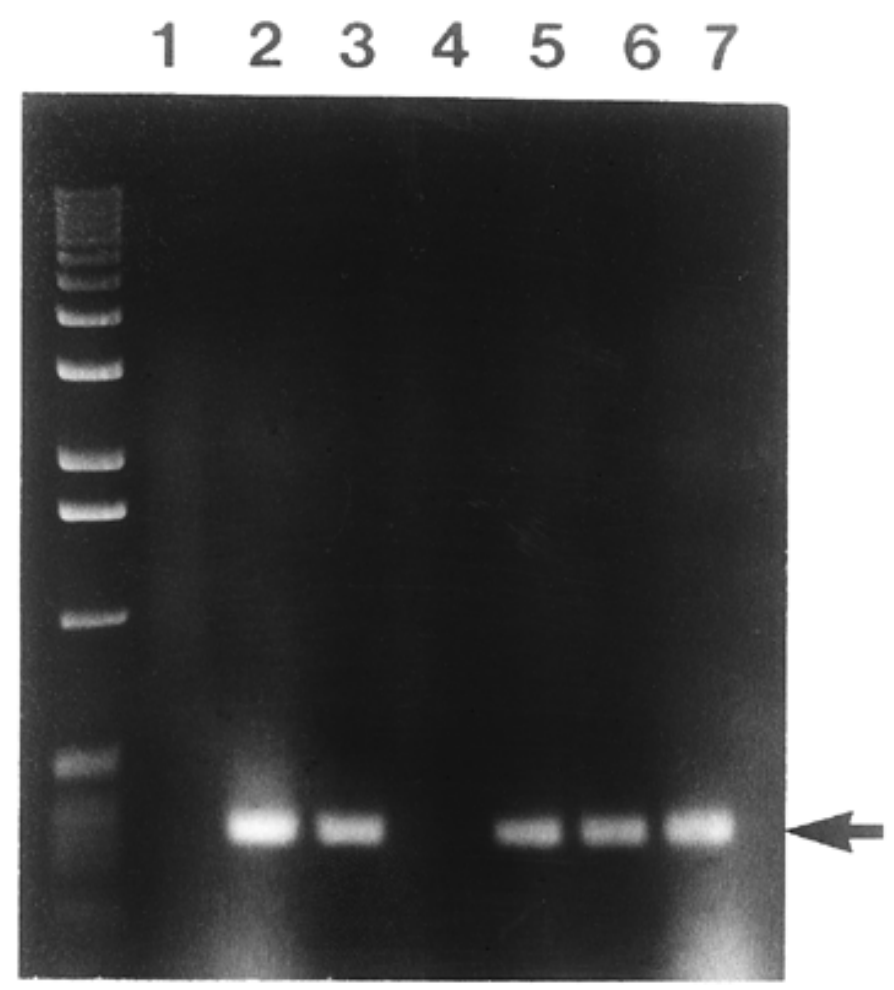

Fig. 3. Detection of MB39 gene integration in MB39-transgenic tobacco lines by polymerase chain reaction directed by primers $\mathrm{C} 1$ and $\mathrm{C} 2$. Left lane, $1-\mathrm{kb}$ DNA ladder (BRL, Gaithersburg, MD); lane 1, DNA from control plant; and lanes 2 through 7, DNA from MB39-transgenic tobacco lines. Arrow indicates the amplified MB39 gene products. 
highest levels of bacterial concentrations $\left(10^{5}\right.$ and $\left.10^{6} \mathrm{CFU} / \mathrm{ml}\right)$. No necrosis was evident in areas infiltrated with bacteria at $10^{4}$ $\mathrm{CFU} / \mathrm{ml}$ or less. Infiltrated plants maintained in the greenhouse showed no subsequent development of necrosis. From this preliminary screening, two transgenic lines (145 \#30 and 145 \#74) containing a single copy of the cecropin gene and showing high levels of disease resistance were selected for further analysis.

Progeny seedlings of self-fertilized transgenic plants from these two transgenic lines, $145 \# 30$ and 145 \#74, also were analyzed for inheritance of the resistance phenomenon. R1 seeds were germinated on MS medium containing $100 \mu \mathrm{g}$ of kanamycin per ml. Five kanamycin-resistant R1 seedlings that segregated from each R0 line were infiltrated individually with all five bacterial inoculum levels. A consistent disease-resistant response was obtained from all five inoculated seedlings, and levels of resistance observed in the R1 seedlings were very similar to those exhibited by the parental R0 lines (Table 2).

Three leaves from R1 seedlings of transgenic lines 145 \#30 and 145 \#74 and control tobacco plants were infiltrated with $P$. syringae pv. tabaci at $10^{4} \mathrm{CFU} / \mathrm{ml}$ to study bacterial multiplication in planta. Peak bacterial growth in the two transgenic lines was about 10 times lower than those in the control plants (Fig. 5), and the leaves showed no necrosis. Bacterial multiplication in the transgenic plants was suppressed, and the bacterial population never reached the minimum level $\left(10^{6} \mathrm{CFU}\right.$ per disk) that appeared to be necessary to cause necrosis in control tobacco leaves. After $60 \mathrm{~h}$, the bacterial population in the resistant transgenic plants declined somewhat. In contrast, bacterial populations in the infiltrated area of leaves from control plants dropped rapidly.

Molecular characterization of transgenic tobacco lines. Transgenic tobacco lines 145 \#30 and 145 \#74, which carried the MB39 gene construct and showed enhanced disease resistance, were analyzed further for MB39 expression by Western blot assay. Proteins from R1 seedlings of transgenic lines 145 \#30 and 145 \#74 produced an antibody-reactive band at about $4.2 \mathrm{kDa}$, the expected $M_{\mathrm{r}}$ predicted for the MB39 protein (Fig. 6). As expected, protein from the control plants did not produce the immunoreactive band. These results demonstrate a positive correlation between disease resistance and MB39 expression in the MB39-transgenic plants. Transgenic tobacco plants expressing MB39 appeared morphologically normal at all developmental stages.

\section{DISCUSSION}

Transformation of crop plants with a specific gene controlled by a highly active constitutive promoter has been a general approach for obtaining transgenic plants with disease resistance against particular pathogens $(2,3,24)$. The approach we describe here differs in that we (i) employed an inducible, rather than a constitutive, promoter and (ii) used it in conjunction with a gene construct designed to secrete the mature gene product out of the cell.

TABLE 2. Disease resistance to Pseudomonas syringae pv. tabaci in R0 and $\mathrm{R} 1$ transgenic tobacco lines $145 \# 30$ and $145 \# 74$ at 7 days after inoculation

\begin{tabular}{|c|c|c|c|c|c|}
\hline \multirow{2}{*}{$\begin{array}{l}\text { Transgenic } \\
\text { line }\end{array}$} & \multicolumn{5}{|c|}{ Inoculum level $(\mathrm{CFU} / \mathrm{ml})^{\mathrm{a}}$} \\
\hline & $10^{2}$ & $10^{3}$ & $10^{4}$ & $10^{5}$ & $10^{6}$ \\
\hline \multicolumn{6}{|l|}{$145 \# 30$} \\
\hline R0 & - & - & - & \pm & + \\
\hline R1 (1) & - & - & - & \pm & + \\
\hline (2) & - & - & - & + & + \\
\hline (3) & - & - & - & + & + \\
\hline (4) & - & - & - & - & + \\
\hline (5) & - & - & - & - & + \\
\hline \multicolumn{6}{|l|}{$145 \# 74$} \\
\hline R0 & - & - & - & + & + \\
\hline R1 (1) & - & - & - & + & + \\
\hline (2) & - & - & + & + & + \\
\hline (3) & - & - & - & + & + \\
\hline (4) & - & - & - & + & + \\
\hline (5) & - & - & - & - & + \\
\hline $\begin{array}{c}\text { Nontransfor } \\
\text { tobacco }\end{array}$ & + & + & + & + & + \\
\hline
\end{tabular}

a - indicates no necrotic lesion observed; + indicates necrotic lesion observed; and \pm indicates partial necrotic lesion observed.

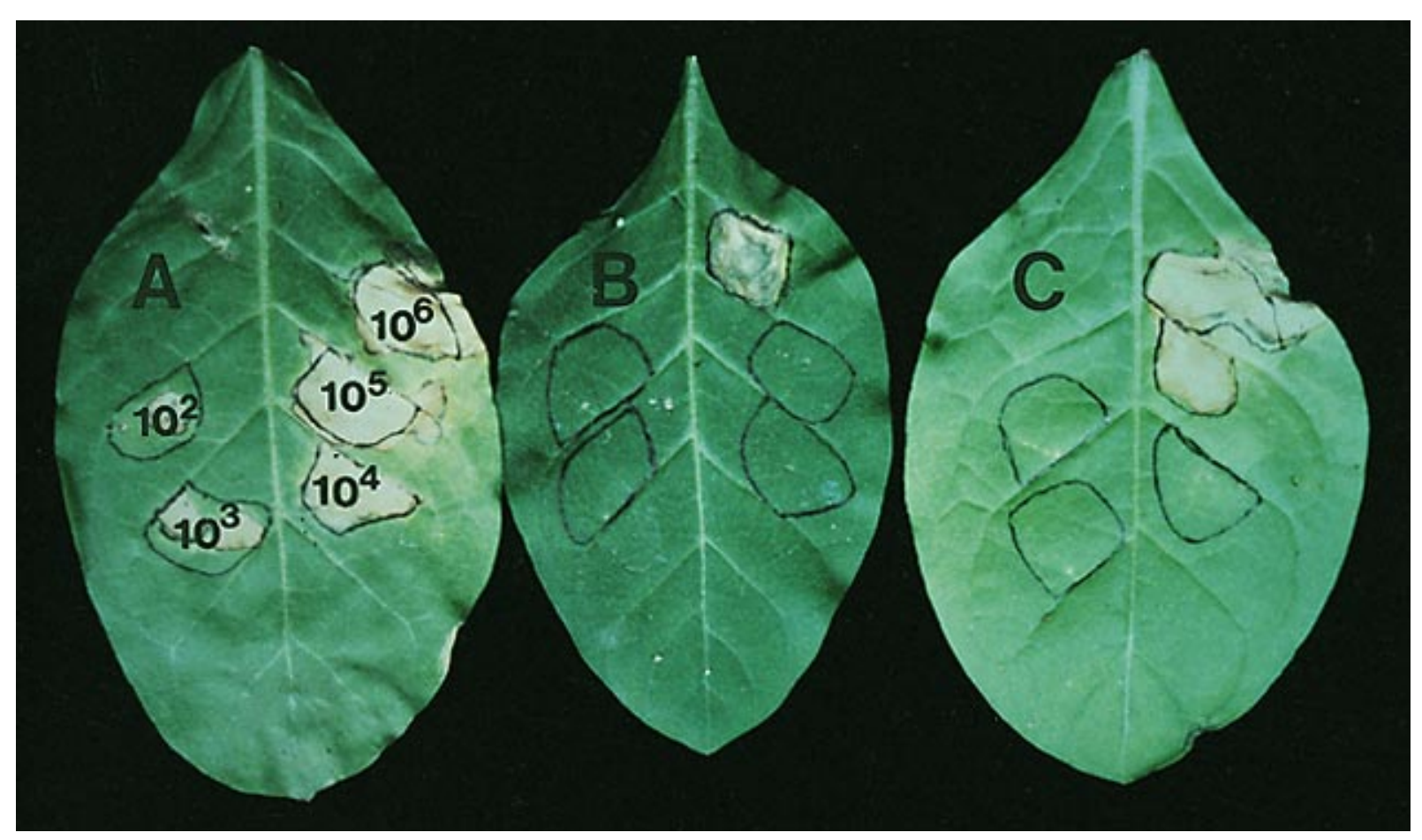

Fig. 4. Wildfire disease symptoms caused by Pseudomonas syringae pv. tabaci strain ATCC 11528R on leaves of control and two MB39-transgenic tobacco plants. Leaves from A, the control plant and $\mathbf{B}$ and $\mathbf{C}$, two R1 seedlings segregated from lines $145 \# 30$ and $145 \# 74$, respectively, were infiltrated with $P$. syringae pv. tabaci at inoculum levels of $10^{2}, 10^{3}, 10^{4}, 10^{5}$, and $10^{6} \mathrm{CFU} / \mathrm{ml}$. The infiltrated areas are indicated by black marker ink. The infiltration pattern in leaf $\mathbf{A}$ is identical to leaves $\mathbf{B}$ and $\mathbf{C}$. Disease development was rated 7 days after inoculation. 
For the first feature, the use of the wound-inducible PiII promoter, previous work indicated that expression of the PiII gene in transgenic tobacco is regulated in the same way as in potato (19) and is induced by bacterial infection (13). Conservation of regulatory functions of defense-related genes in different plants has been observed with other defense genes, such as phenylalanine ammonia-lyase and chalcone synthase $(11,12)$. Use of the PiII promoter has a potential advantage over strong constitutive promoters in that it allows only a low level of MB39 expression in the absence of wounding or infection. However, upon wounding or infection, the PiII promoter provides rapid and systemic activation of MB39. Once the infection is overcome, the PiII promoter would presumably resume its original lower level of activity, providing an economy to the plant.

The second feature of our fusion construct is the secretory sequence of $\alpha$-amylase fused upstream of the MB39 coding region. The N-terminal signal peptide encoded by this sequence presumably directs secretion of mature MB39 cecropin to the intercellular spaces, wherein reside the invading bacteria. Use of these two features, the pathogen-inducible promoter and the secretory sequence, led to the production of transgenic plants with enhanced levels of resistance to wildfire disease and the ability to suppress growth of $P$. syringae pv. tabaci infiltrated into leaf intercellular spaces. Although secretion of mature MB39 to the intercellular spaces remains to be demonstrated, it is interesting that a cytoplasmically expressed cecropin gene (SB-37) failed to provide significant resistance to B. solanacearum (16) and a secreted cecropin A gene product failed to provide useful resistance to $P$. syringae pv. tabaci (9).

The tobacco wildfire disease symptom caused by $P$. syringae pv. tabaci is characterized by distinct chlorotic halos due to the action of a dipeptide toxin $(30,31)$. The active form of this toxin, tabtoxinin- $\beta$-lactam, is a general glutamine synthase inhibitor (23) that affects the enzyme in plants (32). Infiltration of leaves with high concentrations of this bacterium results in necrotic disease symptoms. For example, in our experiments, infiltration of leaves with inoculum levels of $10^{6} \mathrm{CFU} / \mathrm{ml}$ or higher led to chlorotic and necrotic symptoms of similar appearance on both control and MB39-transgenic plants (Fig. 4). However, when different inoculum levels of $P$. syringae pv. tabaci were used for infiltration,

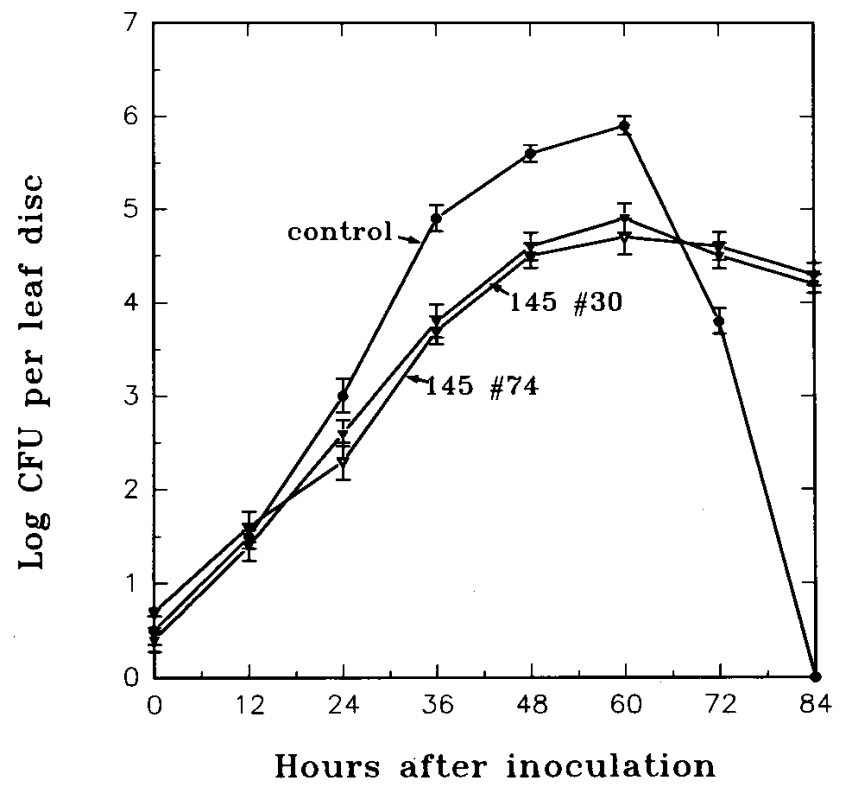

Fig. 5. Time course of the growth rate of Pseudomonas syringae pv. tabaci strain ATCC 11528R in intercellular spaces of leaves from control tobacco plants and R1 seedlings of two MB39-transgenic lines, 145 \#30 and 145 \#74. A bacterial concentration of $10^{4} \mathrm{CFU} / \mathrm{ml}$ was infiltrated into leaf intercellular spaces. Vertical error bars denote standard deviation $(n=3)$. quantitative differences in resistance could be observed among the MB39-transgenic plants. This formed the basis of an R0 screening assay that is simple, rapid, and accurate. In pathogenicity testing, the necrotic lesions in MB39-transgenic tobacco lines spread beyond the infiltrated area when high doses of ATCC 11528R were applied. In contrast, similar symptoms normally were observed on the control plants at lower dosages of the same bacterial pathogen.

Investigation of bacterial population changes in tobacco leaves between MB39-transgenic lines and control plants revealed that the bacterial population in MB39-transgenic tobacco lines was about 10 times lower than that in control plants. The bacterial population in control plants reached $10^{6} \mathrm{CFU}$ per disk at $60 \mathrm{~h}$ after infiltration, which appeared to be the minimum cell number required to induce necrosis in tobacco leaves. In contrast, the bacterial population in MB39-transgenic plants never reached $10^{6} \mathrm{CFU}$ per disk. Sixty hours after inoculation, the bacterial population declined gradually in MB39-transgenic tobacco lines but decreased rapidly in control plants probably due to the necrosis that developed in an infiltrated area where the bacterial population reached $10^{6} \mathrm{CFU}$ per disk. Although the mechanisms for bacterial population decline in MB39-transgenic plants is not well understood, accumulation of MB39 protein might result in reduction of the bacterial population within and surrounding the bacteria-infiltrated area of MB39-transgenic plants. In an in vitro assay, Jaynes et al. (16) conducted a cytotoxic activity assay with the cecropin derivative peptide SB-37 against various pathogenic bacteria. The $\mathrm{LC}_{50}$ value $\left(\mathrm{LC}_{50}\right.$ is the concentration necessary to kill $50 \%$ of the tested organisms) for $P$. syringae pv. tabaci was $0.2 \mu \mathrm{M}$. Therefore, it is possible that the MB39-transgenic lines that showed significant resistance to $P$. syringae pv tabaci had cecropin concentrations around or above $0.2 \mu \mathrm{M}$ in leaf tissues.

Although our inoculation method, which used different bacterial dilutions, was able to show quantitative differences in resistance of MB39-transgenic tobacco lines to P. syringae pv. tabaci infection, mechanical infiltration of bacterial inoculum into leaf tissue is still quite different from the way normal infection occurs. In an attempt to mimic natural infection, we conducted a preliminary inoculation test, using a sprinkler to spray a bacterial suspension onto the leaves of both MB39-transgenic and control tobacco plants. A significantly higher density of necrotic lesions subsequently was

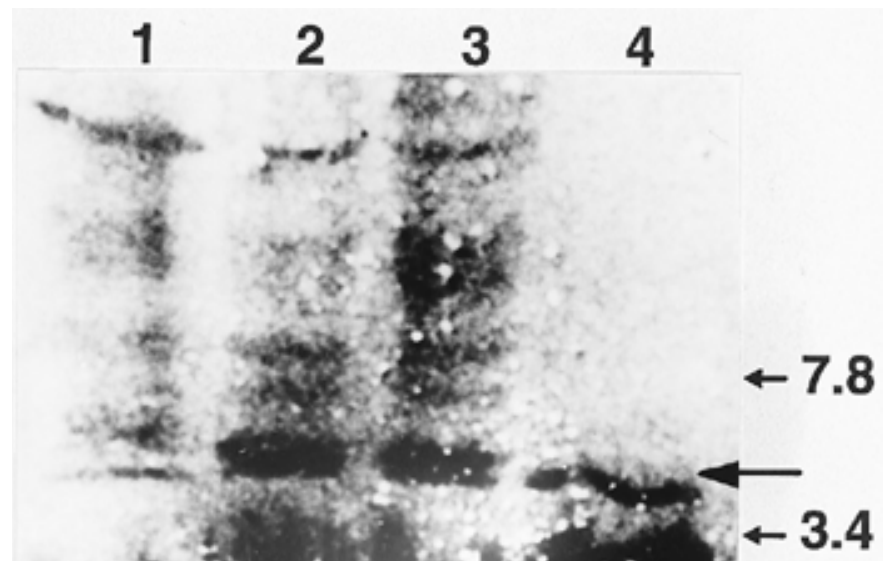

Fig. 6. Western blot analysis of MB39-transgenic tobacco plants. Total crude protein extracts $(50 \mu \mathrm{g})$ from control and R1 transgenic plants were separated on $15 \%$ sodium dodecyl sulfate-polyacrylamide gel, transferred onto nitrocellulose, and reacted with MB39 antiserum. Lane 1, protein extract from control tobacco plant; lanes 2 and 3, protein extracts from transgenic lines 145 \#30 and $145 \# 74$, respectively; and lane 4, purified MB39 protein. The large arrow indicates the expected size of the MB39 protein. The authentic MB39 peptide in lane 4 showed slightly higher mobility than the immunoreactive bands in lanes 2 and 3. This is probably due to the high salt concentration used in the MB39 peptide preparation. The Western blot assay was conducted seven times and showed a consistent reaction pattern with some nonspecific background due to low quality antiserum. 
observed on leaves of control plants than on MB39-transgenic plants (data not shown).

Previous workers reported increased disease resistance against the wildfire pathogen after introducing an acetyltransferase gene that encodes an enzyme that detoxifies the phytotoxin produced by this bacterium into plants (1). Using a similar strategy, De La FuenteMartinez et al. (6) introduced an ornithine carbamoyltransferase gene into plants to detoxify phaseolotoxin produced by $P$. syringae pv. phaseolicola. Because detoxification of the phytotoxin exuded by each pathogen is highly specific, this strategy requires that different genes be introduced to protect against different pathogens. Moreover, this strategy is limited to the few pathogens known to cause disease by synthesis of phytotoxins.

In contrast, the approach described here is less specific and potentially more effective against a broader range of bacterial pathogens. Also, because the action of lytic peptides is targeted to a functional unit of the cell membrane of many bacterial pathogens (33), it may be more difficult for the pathogen to develop tolerance to cecropin-like peptides in planta.

One concern about pathogen-defense strategies involving lytic peptides is their possible toxicity to plant and mammalian cells. From previous work, it is known that the minimum lethal concentrations of cecropin derivatives for plant protoplasts, intact cells, and tissues are generally much higher than those required to kill bacterial cells $(25,27)$. Further, we observed no deleterious effects on transgenic plants expressing MB39 at various levels. Finally, Jaynes et al. (15) reported little effect of these lytic peptides on the viability of mammalian cells even at high concentrations. This, perhaps, is not surprising, because cecropins are similar in structure and function to a growing number of microbial-lytic polypeptides being discovered in cereals and other crop plants as components of their pathogen-defense mechanisms (34).

\section{ACKNOWLEDGMENTS}

We thank J. Jaynes for providing the cecropin gene, D. K. Willis for Pseudomonas syringae pv. tabaci strain ATCC 11528R, L. Willmitzer for the PiII promoter gene construct, and S. Muthukrishnan for the barley $\alpha$ amylase 2 gene.

\section{LITERATURE CITED}

1. Anzai, H., Yoneyama, K., and Yamaguchi, I. 1989. Transgenic tobacco resistance to a bacterial disease by the detoxification of a pathogenic toxin. Mol. Gen. Genet. 219:492-494.

2. Beachy, R. N., Loesch-Fries, S., and Tumer, N. E. 1990. Coat proteinmediated resistance against virus infection. Annu. Rev. Phytopathol. 28: 451-474.

3. Broglie, K., Chet, I., Holliday, M., Cressman, R., Biddle, P., Knowlton, S., Mauvais, C. J., and Broglie, R. 1991. Transgenic plants with enhanced resistance to the fungal pathogen Rhizoctonia solani. Science 254:11941197.

4. Casteels, P., Ampe, C., Jacobs, F., Vaeck, M., and Tempst, P. 1989. Apidaecins: Antibacterial peptides from honeybees. EMBO J. 8:2387-2391.

5. Cooley, M. B., D'Souza, M. R., and Kado, C. I. 1991. VirC and VirD operons of the Agrobacterium Ti plasmid are regulated by the ros chromosomal gene: Analysis of the cloned ros gene. J. Bacteriol. 173:2608-2616.

6. De La Fuente-Martinez, J. M., Mosqueda-Cano, G., Alvarez-Morales, A., and Herrera-Estrella, L. 1992. Pathogen-derived strategy to produce transgenic plants resistant to the bacterial toxin phaseolotoxin. Pages 579586 in: Advances in Molecular Genetics of Plant-Microbe Interactions. E. W. Nester and D. P. S. Verma, eds. Kluwer Academic Publishers, Dordrecht, Netherlands.

7. Destefano-Beltran, L., Nagpala, P., Cetiner, S., Dodds, J. H., and Jaynes, J. M. 1990. Enhancing bacterial and fungal disease resistance in plants. Pages 205-221 in: The Molecular and Cellular Biology of the Potato. M. Vayda and W. Park, eds. CAB International, Wallingford, England.

8. During, K., Fladung, M., and Lorz, H. 1992. Antibacterial resistance of transgenic potato plants producing T4 lysozyme. Pages 573-577 in: Advances in Molecular Genetics of Plant-Microbe Interactions. E. W. Nester and D. P. S. Verma, eds. Kluwer Academic Publisher, Dordrecht, Netherlands.
9. Hightower, R., Baden, C., Penzes, E., and Dunsmuir, P. 1994. The expression of cecropin peptide in transgenic tobacco does not confer resistance to Pseudomonas syringae pv. tabaci. Plant Cell Rep. 13:295-299.

10. Horsch, R. B., Fry, J. E., Hoffmenn, N. L., Eichholtz, D., Rogers, S. G., and Fraley, R. T. 1985. A simple and general method for transferring genes into plants. Science 227:1229-1231.

11. Huang, Y., and McBeath, J. H. 1994. Bacterial induced activation of an Arabidopsis phenylalanine ammonia-lyase promoter in transgenic tobacco plants. Plant Sci. 98:25-35.

12. Huang, Y., and McBeath, J. H. 1994. Differential activation of the bean chalcone synthase gene in transgenic tobacco by compatible and incompatible strains of Pseudomonas solanacearum. Plant Sci. 103:41-49.

13. Huang, Y., McBeath, J. H., Lockwood, H., and Owens, L. D. 1992. Expression of cecropin B controlled by plant inducible promoters in transgenic tobacco plants confers enhanced resistance to Pseudomonas solanacearum. (Abstr.) Phytopathology 82:1101.

14. Hultmark, D., Engstrom, A., Bennich, H., Kapur, R., and Boman, H. G. 1982. Insect immunity: Isolation and structure of cecropin D and four minor antibacterial components from cecropia pupae. Eur. J. Biochem. 127:207-217.

15. Jaynes, J. M., Julian, G. R., Jeffers, G. W., White, K. L., and Enright, F. M. 1989. In vitro effect of lytic peptides on normal and transformed mammalian cell lines. Peptide Res. 2:157-160.

16. Jaynes, J. M., Nagpala, P., Destefano-Beltran, L., Huang, J. H., Kim, J. H., Denny, T., and Cetiner, S. 1993. Expression of a cecropin B lytic peptide analog in transgenic tobacco confers enhanced resistance to bacterial wilt caused by Pseudomonas solanacearum. Plant Sci. 85:43-54.

17. Jaynes, J. M., Xanthopoulos, K. G., Destefano, L., and Dodds, J. H. 1987. Increasing bacterial disease resistance in plants utilizing antibacterial genes from insects. BioEssays 6:263-270.

18. Junghans, H., and Metzlaff, M. 1990. A simple and rapid method for the preparation of total plant DNA. Biotechniques 8:176.

19. Keil, M., Sanchez-Serrano, J. J., and Willmitzer, L. 1989. Both woundinducible and tuber specific expression are mediated by the promoter of a single member of the potato proteinase inhibitor II gene family. EMBO J. 8:1323-1330.

20. Klement, Z. 1963. Method for the rapid detection of the pathogenicity of phytopathogenic pseudomonads. Nature (Lond.) 199:299-300.

21. Knox, C. A. P., Sonthayanon, B., Chandra, G. R., and Muthukrishnan, S. 1987. Structure and organization of two divergent $\alpha$-amylase gene from barley. Plant Mol. Biol. 9:3-17.

22. Laemmli, U. K. 1970. Cleavage of structural proteins during the assembly of the head of bacteriophage T4. Nature (Lond.) 227:680-685.

23. Langston-Unkefer, P. L., Macy, P. A., and Durbin, R. D. 1984. Inactivation of glutamine synthase by tabtoxinine-3-lactam. Plant Physiol. 76:7174.

24. Meeusen, R. L., and Warren, G. 1989. Insect control with genetically engineered crops. Annu. Rev. Entomol. 34:373-381.

25. Mills, D., Hammerschlag, F. A., Nordeen, R. O., and Owens, L. D. 1994. Evidence for the breakdown of cecropin B by proteinases in the intercellular fluid of peach leaves. Plant Sci. 104:17-22.

26. Murashige, T., and Skoog, F. 1962. A revised medium for rapid growth and bioassay with tobacco tissue culture. Physiol. Plant 15:473-497.

27. Nordeen, R. O., Sinden, S. L., Jaynes, J. M., and Owens, L. D. 1992. Activity of cecropin SB-37 against protoplasts from several plant species and their bacterial pathogens. Plant Sci. 82:101-107.

28. Owens, L. D. 1995. Strategies for developing horticulturally useful genes: Overview of gene availability, identification and regulation. HortSci. 30: 957-961.

29. Pene-Cortes, H., Sanchez-Serrano, J., Rocha-Sosa, M., and Willmitzer, L. 1988. Systemic induction of proteinase inhibitor-II gene expression in potato plants by wounding. Planta 174:84-91.

30. Stewart, W. W. 1971. Isolation and proof of structure of wildfire toxin. Nature (Lond.) 229:174-178.

31. Taylor, P. A., Schnoes, H. K., and Durbin, R. D. 1972. Characterization of chlorosis-inducing toxins from a plant pathogenic Pseudomonas sp. Biochem. Biophys. Acta 286:107-117.

32. Thomas, M. D., Langston-Unkefer, P. J., Uchytil, T. F., and Durbin, R. D. 1983. Inhibition of glutamine synthase from pea by tabtoxinine- $\beta$-lactam. Plant Physiol. 71:912-915.

33. Vaara, M., and Vaara, T. 1994. Ability of cecropin B to penetrate the enterobacterial outer membrane. Antimicrob. Agents Chemother. 38:2498-2501.

34. Vigers, A. J., Roberts, W. K., and Selitrennikoff, C. P. 1991. A new family of plant antifungal proteins. Mol. Plant-Microbe Interact. 4:315-323.

35. Wolpert, T. J., and Dunkle, L. D. 1983. Alterations in gene expression in sorghum induced by the host-specific toxin. Proc. Natl. Acad. Sci. USA 80:6576-6580. 